\title{
Snow Cover and Glacier Change Study in Nepalese Himalaya Using Remote Sensing and Geographic Information System
}

\author{
Arun Bhakta Shres tha' ${ }^{\mathbf{1}}$ and Sharad Prasad Jos hi ${ }^{\mathbf{2}}$ \\ ${ }^{1}$ International Centre for Integrated Mountain Development, Nepal \\ E-mail: abshrestha@icimod.org \\ ${ }^{2}$ Water and Energy Commission Secretariat, Nepal
}

\begin{abstract}
Snow cover and glaciers in the Himalaya play a major role in the generation of stream flow in south Asia. Various studies have suggested that the glaciers in the Himalaya are in general condition of retreat. The snowline is also found to be retreating. While there are relatively more studies on glaciers fluctuation in the Himalaya, studies on snow cover is relatively sparse.

In this study, snow cover and glacier fluctuation in the Nepalese Himalaya were studied using remote sensing techniques and geographic information system. The study was carried out in two spatial scales: catchments scale and national scale. In catchments scale two catchments: Langtang and Khumbu were studied. Intermittent medium resolution satellite imageries (Landsat) were used to study the fluctuation in snow cover and glacier area in the two catchments. In the national scale study coarse resolution (MODIS) imageries were used to derive seasonal variations in snow cover.
\end{abstract}

An indication of decreasing trend in snow cover is shown bythis study, although this result needs verification with more data. The snowline elevation is in general higher in Khumbu compared to Langtang. In both catchments, snowline elevation are higher in east, south-east, south and south-west aspects. The areas of snow cover in those aspects are also greater. The study provides the first multi-year temporal variation in snow cover extent in Nepal. According to the analysis of MODIS data, the snow cover extent over the country is highest during late winter and spring, while it is lowest during summer monsoon season. The snow cover area shows dynamic nature and the variability during late winter and spring is quite large.

The snow covered territory of Nepal was divided into four subsections: east, central, west and far-west, and snow line elevations for these subsections were derived from MODIS data. Generally, the snowline elevation is lower in the west than in the east, although the central region shows relatively lower snowline elevation, not following the general zonal trend.

Key Words: Snow cover, glacier fluctuation, satellite imageries, trend, snowline 


\section{INTRODUCTION}

Many studies have shown that the glaciers in the Nepalese Himalaya are shrinking at rather fast rates (e.g. Shrestha et al., 2004; Yamada, 1992; Fujita, et.al, 2001a, Fujita et.al, 2001b). Studies on the status of snow cover in this region, however, is rare. Limited studies based on satellite records indicate that the Northern Hemisphere annual snow-cover extent (SCE) has decreased by about 10\% since 1966 over both the Eurasian and American continents. Reduction in snow cover during the mid- to late 1980s was strongly related to temperature increases in snow covered areas.

Due to the large topographical variation and inaccessibility of many places of the Himalaya, remote sensing is the most appropriate technique to study the snow cover extent and its temporal variation with season. Snow cover fluctuation has implications on downstream river flows of snow fed rivers. In rivers fed by snow and glaciers, melting snow and glaciers contribute a significant amount of water during dry periods, when the water availability is most crucial.

Vast amount of snow in the Himalayas also plays an important role in monsoon circulation. An inverse relationship between the strength of monsoon and the extent of snow cover in the preceding season has been documented by various authors (e.g Barnett et al., 1991; Khandekar 1991; Verneker, et.al., 1995). Based on the short-term observed data from the field, various au thors have tried to study the climate of Himalaya focusing mainly on the Khumbu area (Ageta, 1976; Yasunari and Inoue, 1978).

Snow and glaciers studies traditionally relied heavily on field studies. The studies conducted in last few decades in the Nepalese Himalaya also concentrated mostly on field based studies such as mass balance studies, hydrological studies, meteorological studies etc. Although these studies provide detailed view on some particular subject,

Journal of Hydrology and Meteorology, Vol. 6, No. 1 rigorous field study in high-mountain areas are often not possible due to remote location, difficult terrain and sometimes even due to social and political unrest. For these reasons, remote sensing has become an increasingly important tool in snow and glacier study, particularly as new analytical techniques are being developed in line with emerging sensor technologies (e.g. Wessels et al., 2002; Kääb et al., 2003).

Remote sensing is widely used in preparing glacier inventories in different part of the world. Keieffer et al (2000) prepared a global inventory of glaciers using ASTER data with complementary data of Landsat ETM+. Paul et al. (2002) prepared Landsat $\mathrm{TM}$ and digital elevation data to generate Swiss glaciers. Casassa et al. (2002) used stereo aerial photography and Landsat TM data to compile the glacier inventory of Chile. Paul (2002) used Landsat TM data to automatically delineate glacier outlines in Tyrol Austria. In Nepal, the first complete glacier inventory was prepared in 2000 by ICIMOD (ICIMOD, 2001). The baseline data used for this study was topographic maps. However for several regions satellite imagery were used to derive the glacier boundaries. Similarly this study used satellite imagery to monitor the changes in glacial lakes in the Nepalese Himalaya. In India, several studies have been conducted on glacial retreat, using remote sensing. Recently, Kulkarni et al. (2005) studied the retreat of Parbati glacier in Himachal Pradesh, India using remote sensing. They found that the glacier had retreated by $578 \mathrm{~m}$ between 1990 and 2001, about $52 \mathrm{~m}$ per year.

Remote sensing based glacier delineation, although is fast and relatively inexpensive method, it has several limitations. Seasonal snow covers and clouds cause significant amount of error in analysis. Clouds have spectral properties very similar to snow and ice and are very difficult to remove in the analysis. Similarly, seasonal snow cover might give a false impression of glacier area. It is therefore, not possible to delineate glacier boundaries using automatic classification techniques and often manual techniques have to be applied. 
RGSL (2003) attempted to develop methods for glacier and lake inventory compilation using remote sensing data, particularly, ASTER imagery. The subjectiveness of manual interpretation was found to be quite significant. Furthermore, the agreement between manual and automatic classification was not found satisfactory for glaciers, whereas, there was good agreement between manual and automatic classification for lakes. Debris covered part of glaciers were found to be extremely difficult areas for automatic classification. Paul(2004) used a combination of multispecteral data (Landsat TM) and digital elevation model (DEM; ASTER) for mapping debris covered glaciers.

Snow cover mapping using remote sensing data has been widely used. Classification of snow cover using automatic techniques are more reliable although highly reflective objects such as clouds and sand may cause significant artifacts in the analysis. Another problem in snow cover study using remote sensing is the highly dynamic nature of snow cover. An accurate analysis requires series of satellite imagery, which might in many cases be a limiting factor due to their relatively high cost. On the other hand, for regional scale studies there are coarse resolution satellite imageries, which are available free of cost. NOAA AVHRR has $1 \mathrm{~km}$ spatial resolution and is freely available. Moreover the temporal coverage is also large (about 3 decades) so trend analysis can also be performed. NOAA AVHRR data are therefore widely used for snow cover study (e.g. Allen et al. 1990; Gesell, 1989; Romanov et al., 2000).

On December 18, 1999, the Terra satellite was launched with a complement of five instruments including the Moderate Resolution Imaging Spectroradiometer (MODIS). Many geophysical products are derived from MODIS data including global snow-cover products. MODIS snow and ice products have been available through the National Snow and Ice Data Center (NSIDC) Distributed Active Archive Center (DAAC) since September 13, 2000. MODIS snow-cover products represent potential improvement to or enhancement of the currently available operational products mainly because the MODIS products are global and 500$\mathrm{m}$ resolution, and have the capability to separate most snow and clouds. The MODIS snow-mapping algorithms are automated, which means that a consistent data set may be generated for long-term climate studies that require snow-cover information. Extensive quality assurance information is stored with the products. The MODIS snow product suite begins with a $500-\mathrm{m}$ resolution, $2330-\mathrm{km}$ swath snow-cover map, which is then gridded to an integerized sinusoidal grid to produce daily and 8day composite tile products (Hall et al., 2002).

Vikhamar and Solberg (2003) conducted snow cover mapping using MODIS data. MODIS estimated snow-cover fractions were compared with snow-cover fraction reference maps derived from two ETM+ images acquired the same days as the MODIS images. The study showed the agreement between the two data range from 88 to $96 \%$. Satellite derived snow cover data is often used in modeling application such as Snowmelt Runoff Modeling (Rango, 1992)

In present study firstly glacial changes in two glaciated catchments of Nepal was studied using intermittent medium resolution satellite (Landsat) imageries. Next, seasonal variations in snow cover was studied using coarse resolution satellite snow cover data (MODIS). The MODIS data was verified against Landsat data for one event. Further, spatial differences in snowline over the country was studied using the MODIS data.

\section{Methodology}

\subsection{Glacier Area}

Glaciers area was analyzed for the Khumbu and Langtang catchments. Data used for catchment scale study are medium resolution satellite imagery. Landsat MSS (1970's) Landsat TM (1980's and 1990's) and Landsat ETM+ (2000's) were the main data for this analysis. Nepalese glaciers are characterized by long debris covered area in the 
lower areas and clean upper areas. Debris covered glaciers have different spectral characteristics from the clean glacier and therefore the process of delineating debris covered and clean glaciers are different. In this study, debris covered and clean glaciers were analyzed separately and later on merged together. Landslide scarp, talus slope, and river banks have similar reflective characteristics as the debris covered glacier. This factor has to be considered while delineating debris covered part of the glacier. Seasonal snow covers mask the actual boundary of the glacier and may give false sense of glacier border, particularly in the clean part of the glacier. Imagery with minimum snow cover had to be chosen for the analysis. The imagery were analyzed in combination with the DEM to delineate the actual glacier boundary. As a result of this analysis a discrete time series of glacier area in Khumbu and Langtang was obtained. Major steps involved in delineating glacier area using Landsat data is given in Figures 1 and 2.
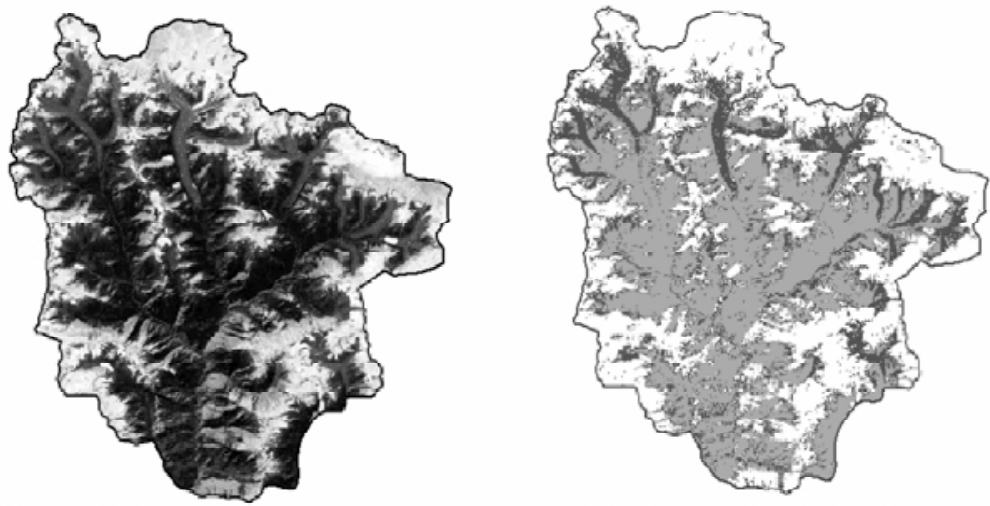

\section{DEBRIS}
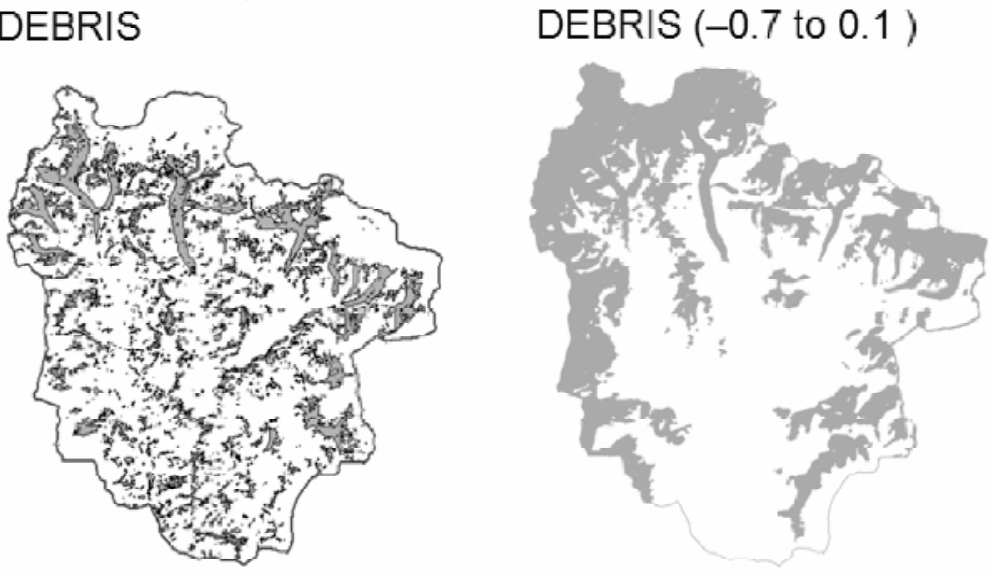

Debris masking

Debris+NDII=Glacier map

\section{$5 \times 5$ filter}

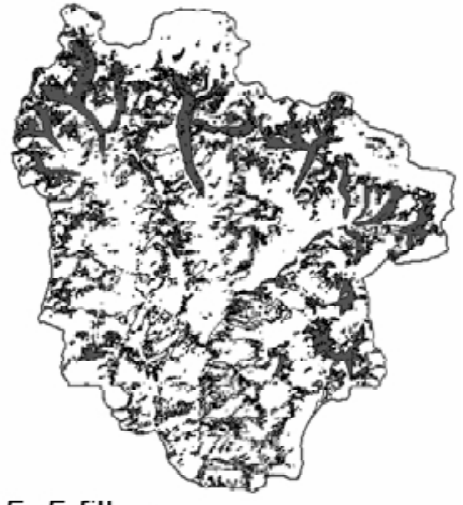

Figure 1: Major steps in delineating glacier area 


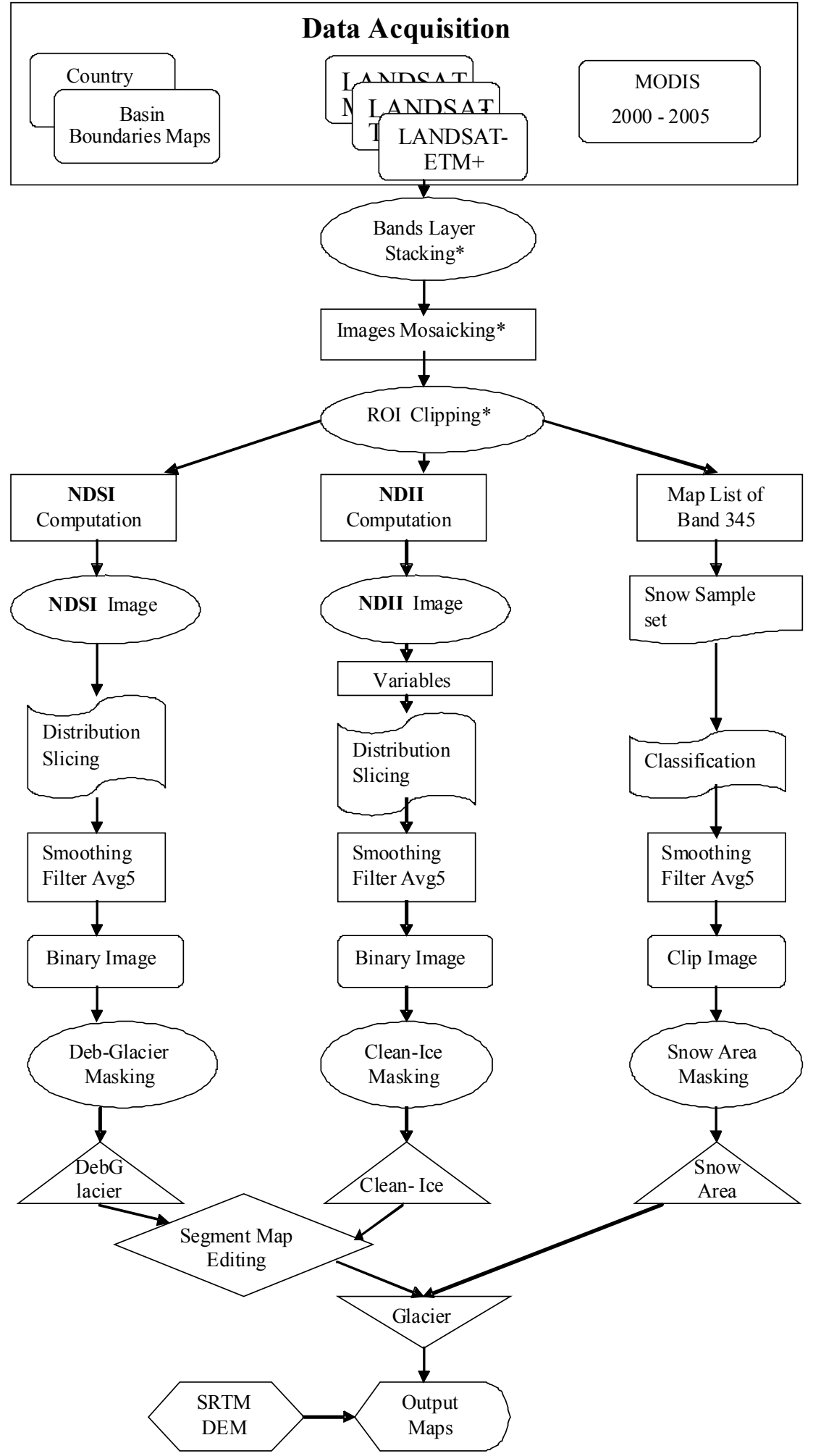

Figure 2: Flow chart of satellite image analysis 


\subsection{SNOW COVER AREA}

Snow cover area was analyzed in two spatial scales: catchment scale and national scale. For catchment scale study, two pilots sties: Khumbu and Langtang are chosen and same Land sat imageries as in the case of glacier delineation were used for snow cover analysis. The raster data thus produced was subject to appropriate filtering, after which the raster data was vectorized. The vector data was manually edited using visible band combination of imagery. The analysis produced a discontinuous time series of snow cover area for these two catchments. The snow cover area was used merely for verifying the snow cover derived from MODIS data.

The lowest elevation of the snow cover was established by overlaying the snow cover layer and DEMand extracting the elevation information. This, in turn gave information about the permanent snow line elevation in the two catchments. For catchment scale study, DEM computed from 1:50,000 scale digital topographic maps was used. The main steps for delineating snow cover areas is similar to those of delineating glacier areas as given in Figure 2.

For national scale study of snow cover, MODIS snow cover product data since 2000 was used. MODIS and Landsat snow covered areas were compared for the two catchments. This analysis provides information about seasonal snow cover fluctuations. As a result permanent snowlines at different parts of the country was established. Suttleborne Radar Topographic Mission (SRTM) DEM was also used to derive the elevation data in the national scale study.

\section{RESULTS AND DISCUSSION}

\subsection{GLACIER AREA}

According to ICIMOD (2001) Khumbu is perhaps the most densely glaciated region of Nepal. There are 213 glacier in Sagarmatha National Park, which occupy $408.9 \mathrm{~km}^{2}$ area and the volume of ice of these glaciers is estimated to be $46.44 \mathrm{~km}^{3}$. Majority of glaciers falls under the category of valley glaciers and represents about $80 \%$ of the total glacier area and about $92 \%$ of total ice reserve in Khumbu. Mountain glaciers are second in terms of area and ice reserve, while other types of glaciers occupy only a minor area and volume. Nguzumpa, Khumbu, Bhote Kosi and Hongu are the four largest glaciers in the area with areas $82.61,45.39,35.63$ and $22.91 \mathrm{~km}^{2}$ respectively.

Information related to glaciers in Khumbu catchment within the boundary of Sagarmatha National Park (SNP) and its Buffer Zone has been derived from the Landsat images of 1976 (MSS), $1992^{\mathrm{TM}}$ and 2000 (ETM). According to present study the glacier areas in Langtang and Khumbu areas in 2000 were 230 and $583 \mathrm{~km}^{2}$ respectively. These figures are not directly comparable with ICIMOD (2001) data, because the catchment area they considered is different from what we considered in this study. Furthermore, the glacial inventory of ICIMOD used rather old data and topographic maps for its preparation. The total glaciated area in Langtang according to this study is $20 \%$ of the catchment area considered, while the corresponding area in Khumbu was $40 \%$. The glaciated area in Langtang and Khumbu in the years 1976, 1992 and 2000 are given in Table 1. Decline in the glaciated area is observed in both catchments.

Table 1. Glacier Area $\left(\mathbf{k m}^{2}\right)$.

\begin{tabular}{|r|c|c|}
\hline \multirow{2}{*}{ Year } & Langtang & Khumbu \\
\cline { 2 - 3 } & $\begin{array}{l}\text { Catchment } \\
\text { Area }=1510.25\end{array}$ & $\begin{array}{l}\text { Catchment } \\
\text { Area }=1475.63\end{array}$ \\
\hline 1976 & 320.50 & 612.90 \\
\hline 1992 & 250.60 & 606.70 \\
\hline 2000 & 230.90 & 583.29 \\
\hline
\end{tabular}




\subsection{SNOW COVER AREA}

Snow areas for years 1976, 1992, and 2000 for Langtang and Khumbu are given in Table 2.

Table 2. Snow cover area $\left(\mathrm{km}^{2}\right)$.

\begin{tabular}{|r|c|c|}
\hline \multirow{2}{*}{ Year } & Langtang & Khumbu \\
\cline { 2 - 3 } & $\begin{array}{l}\text { Catchment } \\
\text { Area }=1510.25\end{array}$ & $\begin{array}{l}\text { Catchment } \\
\text { Area }=1475.63\end{array}$ \\
\hline 1976 & 53.39 & 177.86 \\
\hline 1992 & 75.53 & 112.00 \\
\hline 2000 & 11.07 & 207.16 \\
\hline
\end{tabular}

The snow cover is significantly more in Khumbu compared to Langtang in all three years. In Khumbu the area occupied by snow ranges from 12 to 14 $\%$ of the total area considered, while in Langtang the area ranges from 4 to $7 \%$ only. From the analysis of the three sets of data no clear trend in snow cover area can be seen. In contrast to the general belief that snow cover is gradually depleting, the latest image under consideration (2000) shows more snow cover area than images of previous years. It is clear from this result that images taken in snapshot basis does not provide clear information on the trend and the series of images have to be analyzed for this purpose. The study is perhaps a test of methodology for delineating snow cover areas.

\subsection{MODIS SNOW COVER AREA}

The time series of snow cover data derived from MODIS images are given in Figure 3. A prominent seasonal cycle is evident from the figure. The maximum snow cover area occurs during winter and spring. Thereafter, the area of snow cover gradually decreases throughout the whole summer. Although monsoon precipitation occurs during the period of June to September, the snow fall occurs in the high elevation areas only and therefore the area of total snow cover is not high during this period. The monsoon images are highly obscured by cloud cover, therefore the confidence on monsoon snow cover data is low. The snow cover in post monsoon is characterized by isolated events of snowfalls causing spikes in snow cover data. The snow cover area in Nepal is highly dynamic. The maximum snow cover areas in the six years of MODIS data is $53,000 \mathrm{~km}^{2}(36 \%)$ and the minimum is $3,000 \mathrm{~km}^{2}(3.4 \%)$. General statistics of snow cover over the period of record is shown in Table 3.

Table 3: Statistics of snow cover $\left(\mathrm{km}^{2}\right)$ in Nepal

\begin{tabular}{|l|r|r|r|r|r|r|r|}
\hline & $2000-2005$ & 2000 & 2001 & 2002 & 2003 & 2004 & 2005 \\
\hline $\max$ & 53,012 & 41,019 & 39,991 & 50,422 & 50,977 & 46,268 & 53,012 \\
\hline min & 3,021 & 3,739 & 3,742 & 3,021 & 4,861 & 3,807 & 3,219 \\
\hline mean & 16,486 & 13,546 & 14,940 & 18,751 & 17,001 & 15,205 & 17,938 \\
\hline stdev & 11,224 & 8,872 & 8,561 & 12,911 & 12,399 & 10,964 & 11,573 \\
\hline CV & 68 & 65 & 57 & 69 & 73 & 72 & 65 \\
\hline
\end{tabular}



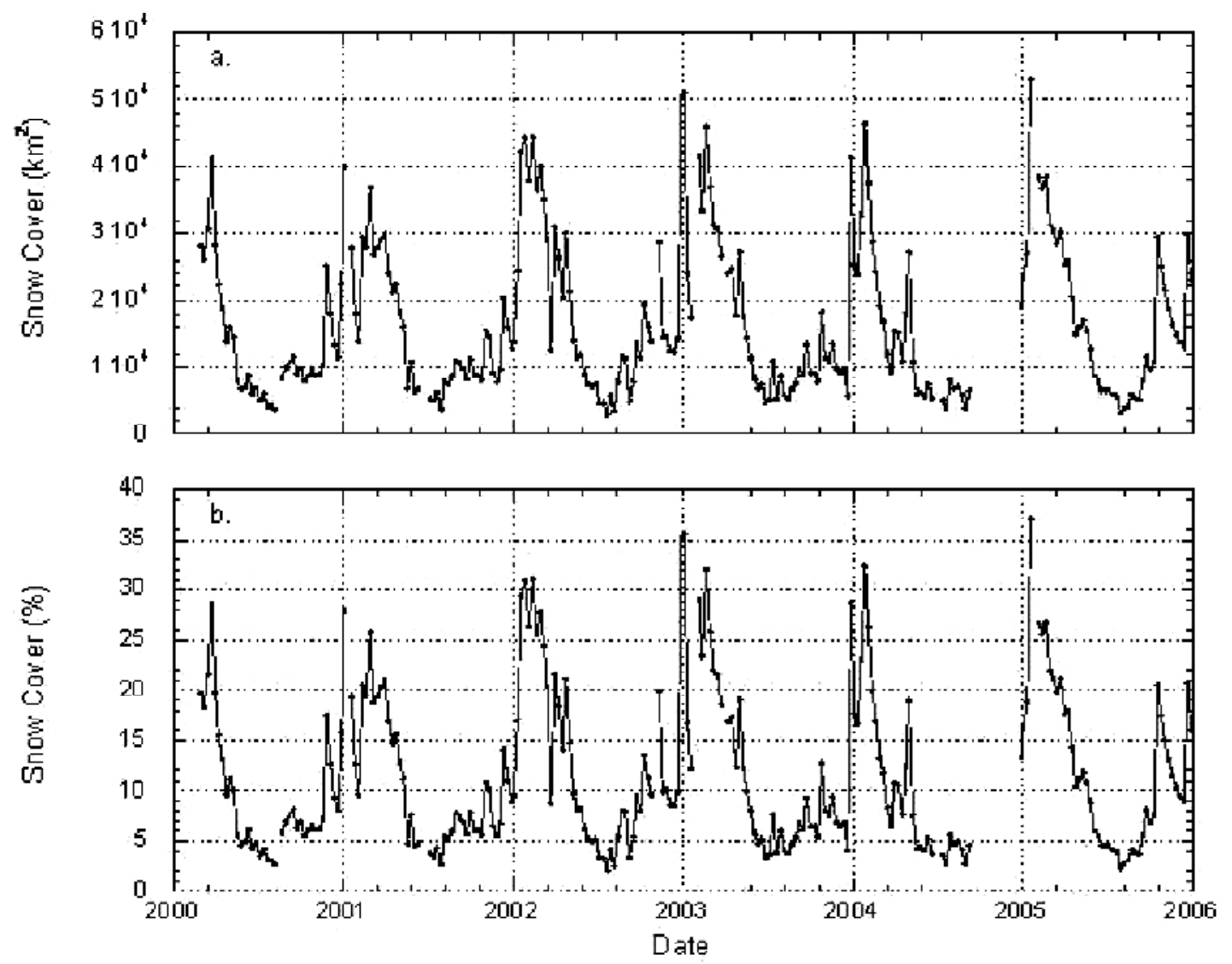

Figure 3: Time series of snow cover derived from MODIS images: a. in $\mathrm{km}^{2}$ and b. in $\%$ of area of Nepal.

Within the period of record there is general trend of increase of about $600 \mathrm{~km}^{2}$ per year. However the 6 years data $(2000-2005)$ is not adequate to perform trend analysis. Assimilation of snow cover data in the future will facilitate trend analysis.

The MODIS snow cover area products were against Landsat derived snow cover data for Langtang and Khumbu catchments. For the verification the MODIS and Landsat data of 31 October 2000 were used. MODIS generally overestimates the snow cover area by about $15 \%$. This could be due to the rather coarse pixel size of MODIS (500m) compared to Landsat (30 m).

The snow cover areas derived from Landsat images were used to derive the snowline elevation in
Langtang and Khumbu. The snowline elevation was considered as the minimum elevation greater than 0.95 percentile. The snowline elevations were differentiated according to the aspects of the ground surface. For this, the ground surface was divided into 8 aspects. The results are shown in Figure 4. Interestingly, greater snow cover areas and higher snowline elev ations occur in the same aspects. In Khumbu, the snow cover is distributed rather unevenly according to the aspect. Predominant snow cover occurs in the eastern aspect, where the snowline elevation is highest, at $5250 \mathrm{~m}$ a.s.1. In Langtang, the snow cover is more or less evenly distributed in eastern, south-eastern, southern and south-western aspects. The snowline elevation is around $5000 \mathrm{~m}$ a.s.l. relatively lower than in Khumbu. 

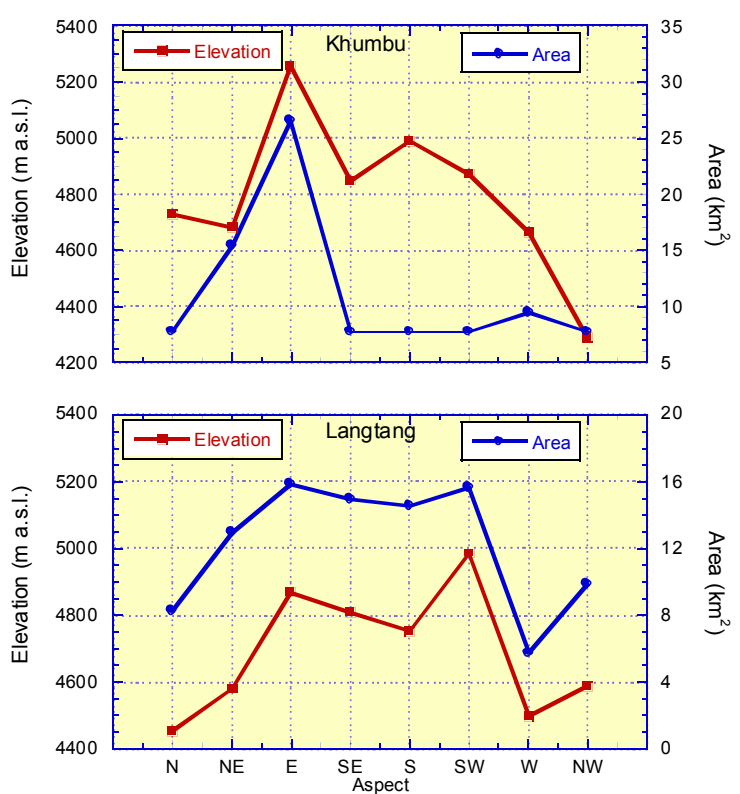

Figure 4: Snowline elevation and snow cover area according to aspect

Figure 5 shows the sub-divisions (east, central, west and far-west) made to study the spatial variations in snowline elevations over the country using MODIS data. For this analysis, an attempt was made to select one day with high amount and another day with minimal snow cover. However this had to be in the post monsoon after most of the seasonal snow was melted. For this we selected Julian day 289 (16 October) and Julian day 305 (11 November) of 2005. There was a precipitation event on Julian day 289 and thereafter it was dry for several weeks and the snow cover depleted gradually to a minimum value in Julian day 305 (Fig. 6 ). The snowline elevation was calculated in the same manner as in the case of catchment scale studies (Langtang and Khumbu).

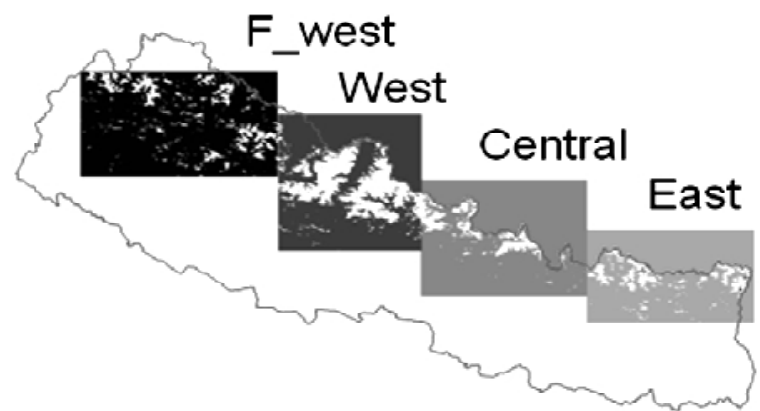

Figure 5: The sub-divisions used to study the spatial variations in snowline elevation using MODIS data

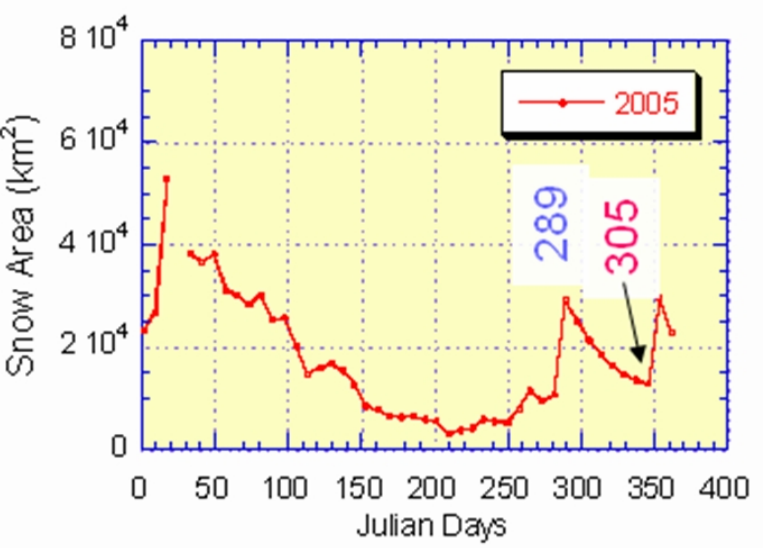

Figure 6: Variations in snow cover in the year 2005

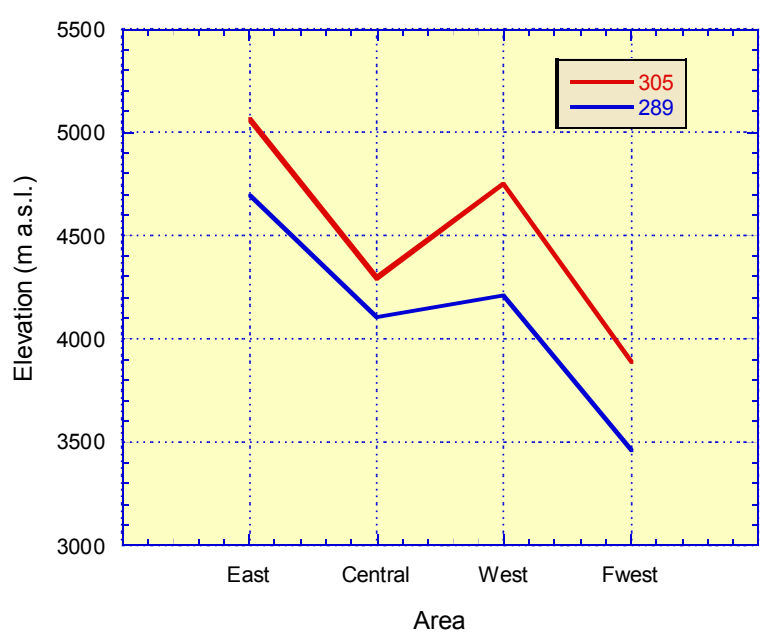

Figure 7: Snowline elevation of the four subdivision for Julian days 289 and 305 of 2005

The snowline elevation for these two days are shown in Figure 7. The snowline elevation shows gradually decreasing trend from east to west. This trend is valid for both dry (305) and wet (289) days. This could be due to gradual northwards migration of the Himalayan axis in the western part of the country. Further, the influence of westerly disturbances could also be the cause behind the lower snowline elevation in the western part of the country. The Central region does not exactly follow the trend and shows comparatively lower snowline elevation. It is felt necessary to further investigate the cause of observed anomaly. This result is in agreement with the catchment scale study with Langtang showing lower snowline elevation compared to Khumbu. 


\section{CONCLUSION}

Present study confirms that remote sensing and geographic information system can be an effective way of monitoring snow cover and glaciers over larger areas, especially where ground based monitoring is lacking. Present study shows a decreasing trend in the glacier areas in two pilot catchments in Nepal: Langtang and Khumbu. Similar trend is also evident in the snowcover, although the data used here is limited and intermittent and the result has to be substantiated by more data.

The study tested the feasibility of using satellite data to derive snowline elevation and spatial differences in snowline elevations. A generally lowering trend in the snowline elevation from east to west of the country is evident from the analysis. Thesnowline derived in this study cannot be inferred as the permanent snowline. For the establishment of permanent snowline a more long-term data is required, whereas the MODIS dataset starts only in 2000. Due to the same reason the trend in snow cover cannot be analyzed. Analysis of NOAA AVHRR data could be of certain use although this data is significantly coarse $(1 \mathrm{~km})$ compared to MODIS. Similar, study with additional data can provide insights on the permanent snowline elevation in different parts of the country.

\section{ACKNOWLEDGEMENT}

The authors acknowledge the support of Nepal National Committee for IHP, UNESCO for the support in the preparation of this research work.

\section{REFERENCES}

Ageta, Y., 1976. Charactersitics of precipitation during monsoon season in Khumbu Himal. Seppyo, 38(Special Issue 1976): 84-88.

Allen, R. C., Durkee, P. A., \& Wash, C. H. (1990). Snow/cloud discrimination with multi- spectral satellite measurements. Journal of Applied Meteorology, 29, 994-1004.

Barnett, T.P., Dümenil, L., Schlese, U., Roeckner, E. and Latif, M., 1991. The Asian snow cover-monsoon-ENSO connection. In: M.H. Glantz, R.W. Katz and N. Nicholls (Editors), Teleconnections linking worldwide climate anomalies. Press Syndicate of the University of Cambridge, Cambridge, pp. 191-225.

Casassa, G., Smith, K., Rivera, A., Araos, J., Schnirch, M., and Schneider, C., 2002, Inventory of glaciers in isla Riesco, patagonia, Chile, based on aerial photography and satellite imagery: Annals of Glaciology, v. 34, p. 373-378.

Fujita, K., Kadota, T., Rana. B., Shrestha, R.B. and Ageta, Y., 2001. shrinkage of Glacier AX010 in shorong region, Nepal Himalayas in the 1990s. Bulletin of Glaciological Research, 18: 51-54.

Fujita, K., Nakazawa, F. and Rana, B., 2001 b. Glaciological observation on Rika Samba Glacier in Hidden Valley, Nepal Himalayas, 1998 and 1999. Bulletin of Glaciological Reaserch, 18: 31-35.

Gesell, G. 1989. An algorithm for snow and ice detection using AVHRR data. An extension to the APOLLO software package. International Journal of Remote Sensing, 10, 897-905.

Hall, D.K., Riggs, G.A., Salomonson, V.V., DiGirolamo, N.E. and Bayr, K.J., 2002. MOIDS snow cover products. Remote Sensing of Environment, 83: 181-194.

ICIMOD, 2001. Inventory of glaciers, glacier lakes and glicial lake outburst floods, monitoring and early warning system in the Hindu Kush-Himalayan Region. Nepal. ISBN 929115331 1, ICIMOD/UNEP, Kathmandu. 
Kääb, A., Wessels, R.L., Haeberli, W., Huggel, C., Kargel, J.S., and Khalsa, S.J.S., 2003, Rapid ASTER imaging facilitates timely assessment of glacier hazard and disasters: EOS, Transactions of American Geophysical Union, v. 84, p. 117-21.

Kieffer, H.H., and et.al., 2000, New eyes in the sky measues glaciers and ice sheets: EOS, transactions of American Geophysical Union, v. 81, p. 270-71.

Khandekar, M.L., 1991. Eurasian Snow Cover, Indian Monsoon and El Nino/Southern Oscillation- A synthesis. AtmosphereOcean, 29: 636-647.

Kulkarni, A.V., Rathore, B.P., Mahajan, S. and P.Mathur, 2005. Alarming retreat of Parbati glacier, Beas Basin, Himachal Pradesh. Current Science, 88: 1844-1850.

Paul, F., 2002, Changes in glacier area in Tyrol, Asutria between 1969 and 1992 derived from Landsat 5 thematic mapper and Austrian Glacier Inventory data: International Journal of Remote Sensing, v. 23 , p. $787-789$.

Paul, F., Huggel, C. and Kääb, A., 2004. Combining satellite multispectral image data and a digital elevation model for mapping debris covered glaciers. Remote Sensing of Environment, 89: 510-518.

Romanov, P., Gutman, G., \& Csiszar, I. (2000). Automated monitoring of snow cover over North America with multispectral satellite data. Journal of Applied Meteorology, 39, 1866- 1880.

Rango, A., 1992. Worldwide testing of the snowmelt runoff model with applications for predicting the effects of climate change. Nordic Hydrology, 23: 155-171.

RGSL, 2003. Method of glacier and lake inventory compilation with specific reference to hazard assessment. R7816, Reynolds Geo-Science Limited, Flintshire.
Shrestha, A.B., Aryal, R. and Rana, B., 2004. Glacier lfuctuation and climatic change in the Nepal Himalaya: A review. Scientific World, 2: 73-77.

Verneker, A.D., Zhou, J. and Shukla, J., 1995. The effect of Eurasian snow cover on the Indian monsoon. Journal of Climate, 8 : 248-266.

Vikharam, D. and Solberg, R., 2003. Snow-cover mapping in forests by constrained linear spectral unmixing of MODIS data. Remote Sensing of Environment, 88: 309323.

Wessels, R., Kargel, J.S. and Kieffer, H.H., 2002. ASTER measurement of supraglacial lakes in the Mount Everest region of the Himalaya. Annals of Glaciology, 34: 399408.

Yamada, T. et al., 1992. Fluctuations of the glaciers from the 1970s to 1989 in the Khumbu, Shorong and Langtang regions, Nepal Himalayas. Bulletin of Glacier Research, 10: 11-19.

Yasunari, T. and Inoue, J., 1978. Charactestics of monsoonal precipitation around peaks and ridges in Shorong and Khumbu Himal. Seppyo: 26-16. 